\title{
ASEAN Intergovernmental Commission on Human Rights: A "toothless tiger" or a prospect for a regional human rights regime in Southeast Asia?
}

\section{Introduction}

In 2007, after 15 years of deliberations on human rights within ASEAN, it espoused the creation of a human rights body in its landmark ASEAN Charter. It came into being in 2009 as the ASEAN Inter-Governmental Commission on Human Rights (AICHR). The odds that AICHR will become a cornerstone of a human rights regime for ASEAN, or perhaps wider East Asia, are elaborated on in this paper. The divergence of opinions on the matter is significant. According to Surin Pitswuan, ASEAN's current secretary general, it is expected to 'pave the way for the growth of democracy and human rights in the region' (ASEAN, 2009a).Thus, he sees the advisory and promotional competences of AICHR in an evolutionary perspective. Critics address its lack of independent enforcement and controlling or monitoring powers, deeming it a "toothless tiger" with little momentum to develop. It is too soon to tell anything definite, but I hypothesise that AICHR can be viably considered as the first piece of an evolving system of human rights protection. A Chinese adage points out that a journey of a thousand miles begins with a single step. This being already done, the following paper focuses on the next ones.

\section{ASEAN Human Rights Cooperation: The Road to AICHR and beyond}

After over four decades of advancing collaboration in many spheres, cooperation on human rights within ASEAN is still in itsinitial stage. During this period ASEAN succeeded in adopting five declarations on human rights issues: The Advancement of Women (1988), Children Plan of Action (1993), Children Commitment (2001), Elimination of Violence against Women (2004) and Rights of Migrant Workers (2006) (CIL NUS, 2012). Those documents are neither legally binding nor do they ensure any concrete steps to be taken, while also failing to provide any 
monitoring or reporting procedures. In 1993, for the first time, ASEAN member states declared a need to establish a regional body on human rights with local characteristics - historical, economic, political and cultural (J. Tang, 2012). In 1995 the Working Group for an ASEAN Human Rights Mechanism (AHRWG) was formed, operating both in individual countries and at the regional level. Human Rights Working Groups were first founded in the Philippines, Thailand, Indonesia, and Malaysia whereas AHRWG began to convene at the annual ASEAN Ministerial Meetings (AMM) and Senior Officials Meetings (SOM). In 1996 the ASEAN Joint Ministerial Communiqué first recognised the AHRWG as a dialogue partner and included a provision stating that the "establishment of an appropriate regional mechanism on human rights should be considered.' In 2000 AHRWG submitted to the AMM a Draft Agreement on the Establishment of the ASEAN Human Rights Commission. It was envisaged as an inter-governmental body, whose mission would be to promote and protect human rights. The Commission was empowered with neither a court of law capacity to issue binding judgments or with abilities to mediate or make recommendations.

The signing of the ASEAN charter during the $13^{\text {th }}$ ASEAN Summit in Singapore in November 2007 introduced the process of human rights into the ASEAN agenda. Rodolfo Severino, the former Secretary General of ASEAN, was quoted as saying that the document would both strengthen the institutionalisation process of ASEAN as well as codify common values recognised by its member states (R. Severino, 2006, p. 381). Adopted during the $14^{\text {th }}$ Summit in Hua Hin, the Charter included human rights among its purposes and announced the imminent establishment of a human rights body. In article 14 of the Charter it is stated: 'In conformity with the purposes and principles of the ASEAN Charter relating to the promotion and protection of human rights and fundamental freedoms, ASEAN shall establish an ASEAN human rights body; this ASEAN human rights body shall operate in accordance with the Terms of Reference to be determined by the ASEAN Foreign Ministers Meeting' (ASEAN, 2007).

Consequently, in 2008 a High Level Panel (HLP) was established during the $41^{\text {st }} A M M$. Foreign ministers and the chiefs of national human rights institutions were assigned as its members. HLP operated for about a year and its chief task was to draft Terms of Reference (TOR) for the budding institution and present it to the AMM for approval. The goal was achieved in July 2009. Finally, the $15^{\text {th }}$ ASEAN Summit adopted the TOR and inaugurated AICHR on the $23^{\text {rd }}$ of October, 2009 (ASEAN, 2009a).

In the TOR it is stated that the purpose of the AICHR is to promote and protect human rights and the fundamental freedom of the peoples of ASEAN (Par. 1.1). Its mandate and functions are to provide advisory services and technical assistance on human rights matters to ASEAN sectoral bodies upon request (Par 4.7). One of chief goals of the body is to develop an ASEAN Human Rights Declaration with a view of establishing a framework for human rights cooperation through various 
ASEAN conventions and other instruments dealing with human rights (Par. 4.2). AICHR shall assess its work and submit recommendations for the consideration of the AMM on future efforts that could be undertaken in the promotion and protection of human rights (Par. 9.7). The TOR also spells out its structure, powers and mode of decision-making. The AICHR is an inter-governmental, consultative body and an integral part of the ASEAN organisational structure (Par. 3). Each ASEAN Member State shall appoint a representative to the AICHR who shall be accountable to the appointing Government (Par. 5.2). The appointing Government may decide, at its discretion, to replace its Representative (Par. 5.6).Decision making shall be based on consultation and consensus in accordance with the article 20 of the ASEAN Charter (Par. 6.1), though AICHR will engage in dialogue and consultation with civil society organisations (Par. 4.8) (ASEAN, 2009b, p. 1-11).

Thus, the mandate of AICHR focuses predominantly on the promotion of human rights - enhancing public awareness through education, research and the dissemination of information. Its role is limited to an advisory body, though both to the ASEAN Secretariat and the member states. It lacks monitoring or investigative capacities. Its recommendations are voluntarily implemented. Its members are appointees of the governments, selected and recalledwith few constraints. Finally, TOR names the „ASEAN Way” approach as compulsory for decision-making (ASEAN, 2009b, p. 7). This mode is reinforced by the treaty norms of ASEAN, which include among others: state sovereignty, non-interference in member states' domestic affairs, primacy of upward consultation and consensus and confrontation avoidance (ASEAN, 2009b, p. 2 and ASEAN, 2007, p. 6). At face value, a hardly optimistic forecast can be made about the operability of AICHR, as there are both formal and informal norms precluding the discussion of human rights violations in a particular country. Even if some members of AICHR want to discuss them, it is relatively easy to remove them from agenda.

Most of the speculated weaknesses of such an approach were exploited in the past by Burmese officials. They were effectively soft-vetoing motions to address human rights violations in Myanmaron the informal level of consultations as well as insisting on strict adherence to the rule of non-interference in internal affairs. ASEAN was hardly able to restrain the Burmese regime from serious human rights violations, like the ones during unrest of Buddhist clergy in 2007, as sanctions were out of question by ASEAN's rules. Since its ascension to ASEAN in 1997 Myanmar has been quite successful in delaying the advancement of human rights cooperation within ASEAN (S. Tadjbakhsh and A. Chenoy, 2007).

Still, the recent political change in Myanmar amounting to the introduction of partial democratic procedures and civic liberties has indirectly authenticated a positive result of many socialising pressures that integration with ASEAN has been exerting on Burmese military elites. It can be argued that regardless of the following intensity and ultimate direction of evolution of the Burmese regime in the long term, at this point it will be much harder for Naypyidaw not to comply 
with the rehashed rules and goals of ASEAN, which espouse human rights. It can be witnessed in its sensible approach to putting an end to the inter-sectarian violence in Rakhine State in 2012. The new Burmese authorities seem to have recently taken up the path of many other ASEAN member states of legitimising rule through mixing soft authoritarianism and economic performance. With due care for their international image on which its economic gains are contingent, Thein Sein and his military support base are likely to be interested in demonstrating their cooperative attitude to the organisation. Even if those practical determinants mentioned above do not rule out obstacles and challenges for the AICHR, they may be taken for are favourable climate for the project of human rights capacity building processes within ASEAN.

\section{AICHR and Asean Way - the intricacies of design}

Founding AICHR upon the ASEAN Wayhas caused differential and often polarised opinions of representatives from governmental and NGO communities. Officials of the ASEAN Secretariat were favourable as this approach to decision-making has been an established feature of the ASEAN diplomatic culture. The intercultural meta-values, procedural norms dubbed the ASEAN Way were developed at the organisation's nascence precisely to address the challenges of collective decisionmaking in the context of ethnic, religious and cultural complexity and diversity of Southeast Asia. Borrowed from the Javanese cultural patterns through an Indonesian contribution to the foundational values of ASEAN, the two key norms of the ASEAN Way are musyawarah and mufakat. The first constitutes the rule of conducting compulsory thorough and informal (confidential) consultations between parties before any official decision-making process is started. During this phase all parties are free from the threat of a public loss of face. They can confront their positions, proposals and test the limits of each other's concessions. The position of neither side is discriminated in the process, while majority decision-making is eschewed. With mufakat, all decisions must be made in accord with the rule of consensus, coupled with a strong dislike of most ASEAN leaders to any form of supranational decision-making, which is associated with arbitrariness, seen as contrary to the ASEAN Way. Moreover, one of top priorities of the process is to sustain the atmosphere of friendship, tolerance, the commonality of interests and mutual understanding, what adversely affects time spent on negotiations and short-term effectiveness, but increases sustainability of reach agreements over the long term.

It is worth noticing that those norms emerged on the regional level against the backdrop of essential disagreements on values among ASEAN member states, though much in synch with the time-honoured East Asian practice of dealing with axiological divergences. The interactions between the multitude of religions and philosophical systems inherent to the region, informing basic assumptions about 
human condition and dignity and so also the attitude to human rights, have long set models for layered normative coexistence. I distinguish five features of East Asian ethical complexes:1. inclusion i.e. eclecticism of beliefs, possibility of following more than one denomination or ethical system; 2 . convergence, i.e. mutual absorption and co-determination in the development of those complexes; 3 . syncretism, i.e. frequent emergence of new denominations based on inclusion and convergence; 4. secularism, i.e. religious moderation and non-fundamentalism, with some exceptions, polytheism or atheism; 5. folkism, i.e. reducing ethical complexity to simple, ritualised daily practice.

These qualities make East Asian axiological systems not only a hybrid set of values but also a changeable one. It should be perceived more as a process, ethics-in-making, rather than a fixed and static ethical perspective. What is more, it seems that the variability of East Asian value subsystems, which has ever constituted a challenge for the identification of a homogenized set of Asian values and has been perceived as an obstacle for the establishment of any regional human rights regime, has also made it necessary to develop sets of meta-values regulating ethical behaviour in a normatively diverse environment. Various strands of neoConfucianism or the Indonesian pancasila ideology are of par excellence, and East Asian decision makers can draw upon such systems of meta-values. The "Asian Values" proposal of Mahathir and Lee Kwan Yew from the early 1990s can be seen as a merger of Malay and Chinese ethical perspectives.

Many observers, notably Western ones, often ignore or abstract from this reality. Brand Adams, executive director of Human Rights Watch's Asia Division, expressed his strong doubts in the effectiveness of the AICHR by saying that there were a few countries in ASEAN that are among the most repressive in Asia, if not in the world and that he could never see how this group could ever agree on anything "with teeth" (T. Johnston, 2012). In a similar vein civil society groups operating in East Asia have challenged and even questioned the legitimacy of the AICHR. In accordance with their recommendations, the ASEAN body would "have teeth" only if it met three conditions: accountability, independence and effectiveness. However, currently they have criticised the AICHR for its dependence on governments, for having neither the capacity for inquiries nor enforcement powers, and for the closed character and secrecy of its working proceedings. They demanded transparency of the AICHR actions, entailing direct access to its meetings and participation in the drafting of the ASEAN Human Rights Declaration (International Justice Resource Centre, 2012).

A moderate perspective was offered by Hao Duy Phan who offered his own idea for a human rights regime for Southeast Asia (H. Phan, 2009a). Considering AICHR in its current version, Phan commented the body as "the elementary advance" in promoting universal human rights in the region as AICHR covers all ASEAN member states. It is "the initial step forward" in moving the organisation from being state-centric to being more people-oriented. At the same time he 
outlined that human rights "can no longer be perceived as a solely domestic issue as there is a forum on human rights within ASEAN" (H. Phan, 2009b). Above all, he presented his novel proposal for a two-pronged evolution of Southeast Asian human rights regime, either supplementary or alternative. In designing it he drew from comparative analyses of existing regional human rights regimes, their instruments and mechanisms (European, Inter-American and African) and from their practices. Phan also used conclusions from a survey covering the subject he had conducted on East Asians involved in human rights activities.

There are two basic pillars envisioned in Phan's idea of a regional human rights system. First of them would be the AICHR, operating under ASEAN and totally subjected to ASEAN principles. It would keep its promotional mandate and the remaining being comprised of governmental representatives, making decisions on the base of the rule of consensus, and securing its intergovernmental status with the intention of elaborating political statements. The second pillar would be the Human Rights Tribunal (SEACHR) operating outside ASEAN, and not subjected to the organisation's principles. The mission of the body would be human rights protection on the basis of opinions made by independent experts. The Tribunal would be a judicial body making decisions using the majority voting rule and issuing legally binding rulings (H. Phan, 2009b). SEACHR would be the stronger, more independent and more effective human rights mechanism in comparison to AICHR that would comprise, at least in the beginning of its existence, of a group of the most human rights-oriented countries of the region, possibly Indonesia, Thailand, Philippines, Malaysia and Timor-Leste (H. Phan, 2009c).

It seems that the SEACHR would be a more complementary than an alternative option to the AICHR, taking into account the other regional human rights regimes mentioned above. They most often have (or had in the case of the European system) a dual structure, consisting of both a commission and a tribunal. The power of the SEACHR would come from its apolitical character and independence of its members who are experts in international law. The main task of the group of specialists would be to conduct investigations on cases of human rights violations and to resolve legal issues in the field of human rights protection. Above all, it would take advantage of the legal character of the decisions and judgments in relation to the states participating in the mechanism in order to provide the regional system with viable instruments of human rights protection (H. Phan, 2009b).

\section{AICHR and ADHR in the context of global and regional human rights regimes}

Representatives of Confucianas well as broader East Asian civilization shave often been put among the most ardent opponents of both the universal concept of human rights as well as the West-originated global regime of their protection. 
According to Michael Freeman, it is necessary to remember that among a group of countries that were significantly engaged in the process of issuing and accepting the Universal Declaration of Human Rights were colonial empires, which at the time were ruling a great majority of the world population through subordination to the metropolis. Since the day that the document was signed the number of UN member states has increased more than threefold. The change put into question whether it is possible in the case of non-Western countries to fully implement the rules included in the document. Freeman notes that the concept of human rights permeating the document, which in fact constitutes the base for the entire structure of the universal human rights regime, is derived directly from John Locke's idea of natural rights. It gives priority to the individual freedom of a person over their duties towards other people and society as well as recognises civil and political rights as more important than collective, economic and social rights (M. Freeman, 2007, p. 43-44).

At the same time, unlike the other world regions (Europe, Africa, Americas), despite a relatively advanced stage of processes of regional integration in ASEAN and through ASEAN-based institutions, no human rights regime, either regional or sub-regional, had been set up until recently. The claim that it is the wide range of different value systems that constitute one of most serious obstacles for its establishment was already partially dismissed in the previous section, emphasising commonalities in this regard in the whole of East Asia. Thus, in agreement with some East Asian IR experts' opinion son the matter I argue that one cannot readily exclude the category of East Asian civilization, with common regional identity as its inherent component, even though it is defined differently than by a simple extrapolation of any of its many inherent normative codes. Therefore there can also exist a prospect for developing a stronger axiological dimension of regional integration in addition to economic and political efforts of community building in ASEAN and in wider East Asia. Still, a value-oriented level of regional integration process is most commonly perceived as a considerably more serious challenge than those more established ones (X. Yu, 2010).

The ASEAN architecture is instructive in this regard. Envisioning a transformative nature of regional values has been a frequent reaction of East Asian officials and academics. For instance, has identified the challenge of civilizational identity building as a key factor in the successive process of integration within the region (R. Severino, 2006, p. 368). Moreover, from a Chinese perspective, over the course of history elements of Confucian ethics have proven to be conductive to a harmonious coexistence between differing ethnic, religious and cultural groups within China. The very concept of zhonghua minzu, embedded in the idea of cultural inclusion, could represent a guideline for the project of East Asian Community building (J. Xiao, 2010). Despite a limited record and influence of Chinese culture in Southeast Asia, which is currently represented mainly by members of the Chinese diaspora, it still constitutes a significant factor of sub-regional 
identity. In fact it is Singapore, a Confucian model state, along with Indonesia (pancasila model state) and Malaysia (multi-cultural consociationalist state) that have had a significant impact on shaping patterns of ASEAN cooperation and integration. The prominence of Singaporean leaders as norm entrepreneurs within ASEAN has been most visible in the "Asian Values" proposal.

In fact the point of convergence of the state-originated models in the field of regional IR is to develop a harmonious "unity in diversity" model of coexistence and cooperation, a phrase borrowed from pancasila. In addition to that, there seems to have been a relatively stable practical consensus amid most ASEAN member states about the attitude to given sets of elementary values. International treaties protecting civil and political rights, in particular the ICCPR, have not been commonly ratified and implemented by most of the representatives of East Asia. For instance, abolishing the death penalty is mostly rejected, being strongly rooted in most of the East Asian penal traditions (including East Asian democracies). The same is largely true for the administrative detention and other measures protecting state security, which are accepted within most of the East Asian societies. However, on the other hand almost all countries in the region have already ratified international treaties protecting rights of women and children as well as WTO treaties protecting workers' rights, though with some reservations referring primarily to freedom of association and forced labour.

In contradiction to the early 1990s when the "Asian values" project was being promoted, which was to a large extent perceived as a political tool for their authoritarian rule and useful for the regional states in rejecting Western calls for human rights protection in East Asia, the current regional effort aiming at elaborating regional ethics seems much less socio-technical. It seems to be genuinely a human rights-oriented project. It differs from its predecessor particularly in that it does not constitute an articulated opposition and alternative towards the human rights concept and practice internationally recognised as universal. There is greater readiness within ASEAN to adjust regional standards to wider international requirements. Still, it should be perceived as a long-term process being strongly embedded in regional contexts, historic, cultural, economic, political, etc.

The best example to depict the phenomenon is the newly adopted ASEAN Human Rights Declaration (AHRD). On one hand it is called by its authors (ten ASEAN Member States) as a landmark development, which is the first document of this kind ever adopted in East Asia. On the other hand it has already been severely criticised, especially by non-governmental organisations that were excluded from both the drafting and issuing of the document. What is more, some international law experts underline that the text of AHRD consists of some ambiguous expressions which constitutes opportunity for misinterpretation, deliberately introduced into the text to placate non-democratic ASEAN governments (P. Gerber, 2012). They point out principles 6 and 7 of the AHRD as such ambiguities (ASEAN, 2012). In accord with the first of them the enjoyment of human rights is 
to be "balanced with the performance of corresponding duties" to other individuals, the community and the society (ASEAN, 2012). In practice it makes human rights conditional upon individuals being "good" citizens. This is inconsistent with international human rights norms according to which it is not dependent upon them being responsible members of society. However, it is worth mentioning that also other non-European regional human rights documents and instruments (in particular the African one and to a lesser extent also the Inter-American one) take a similar stance and make human rights conditional on some particular obligations (e.g. see article 27 of the African Charter of Human and Peoples Rights) (Human Rights Library, 2012), even though they are partially inspired by European patterns and solutions. According to another one of the controversial AHRD principles, "the realization of human rights must be considered in the regional and national context bearing in mind different political, economic, legal, social, cultural, historical and religious backgrounds (ASEAN, 2012). Moreover, human rights can be limited due to some specific causes including "national security", "public order" and "public morality" (ASEAN, 2012).

In fact none of the specific reservations mentioned above towards universally recognized human rights standards has proven to be a surprise from the perspective of relevant epistemic communities. This is especially relevant when taking into consideration all the elements of the regional context and long-term politics of East Asian states towards human rights issues. In addition to those long-known principles and procedural norms of regional cooperation and integration within ASEAN such as primacy of upward consultation and consensus, avoiding confrontation or non-interference in member-state`s domestic affairs, there is the final factor of specificity of internal socio-political governance within East Asian states; even among nominal East Asian democracies like South Korea, where priority is given to internal state security over individual rights and freedoms of citizens.

Nevertheless, both the "behind closed doors" issuing process of the AHRD as well as all the reservations to the universal human rights in the document have provided its critics with some moderately legitimate arguments against the Declaration. Touching on the first problem the UN High Commissioner for Human Rights, Navi Pillay, observed that this "was not the hallmark of the democratic global governance" to which ASEAN aspires (the Office of the High Commissioner for Human Rights, 2012), while pointing out the other issue. Human Rights Watch have insisted that taking advantage of some "weasel" words (P. Gerber, 2012) included in the ADHR, ASEAN governments will be allowed to escape from their human rights obligations. This would become an even greater disappointment if a prospect of future ASEAN Human Rights Convention, possibly including the same constraints towards universal human rights treaties, is taken into account (P. Gerber, 2012). 
In the author's opinion in the process of analysing the text of the ADHR one should refer equally to supportive and critical evaluations of the document as it seems that at least to some extent both sides are correct in their opinions. Firstly, one cannot deny the pioneering character of the document, which has proven to be the following step forward after the establishment of the AICHR. It provides the newly established body with a politically binding international human rights document to which not only the ASEAN member states but also either representatives of non-governmental societies or pro-democratic East Asian governmental partners may refer to if necessary. Of course there is still a need to issue a proper convention on human rights of a legally binding character to complete the basics of the sub-regional human rights system. For the time being both elementary components of the ASEAN human rights regime in statu nascendi seem to be "jewels" that need to be "grinded" as they have much room for improvement. Still, as a Chinese proverb says: "Better a diamond with a flaw than a pebble without one" (P. Gerber, 2012). At the same time it would be hard to imagine the progress of the regional human rights regime in a direction that deprived it from its Southeast Asian specificities. Firstly it is because its authors' intentions are likely to preserve the role of the "ASEAN way" in the emerging system. Secondly, notwithstanding the fact that it is expected to comply with some internationally recognized patterns it is still being primarily designed to fit local conditions. The search for balance between universal versus local solutions seems to be the most significant challenge for the prospect of ASEAN human rights regime as its leaders are unwilling to accept the highest possible (read: Western) standards of individual human rights and freedoms and not being able to implement a great portion of them. The cautionary case is the African Charter of Human and Peoples' Rights which to a large extent mirrors the principles of the European Convention of Human Rights, but lacks institutions guaranteeing the power to implement it. On the other hand, in relation to the AHRD there is a need for Dialogue Partners of ASEAN, especially those with experience in developing national systems of human rights protection like Australia, Japan or the US, to be involved in the improvements of the regional human rights system as well as in the practical advancement of wellbeing and security of the ASEAN societies.

\section{Conclusion}

When making for recasts regarding the evolving human rights regime in Southeast Asia three issues need to be considered. Firstly, the ASEAN Declaration on Human Rights that has recently been adopted. Its provisions are ambiguous and often contradictory with one another, so what interpretation of the document will take precedence over others is a crucial issue. Secondly, certainly there is a great need for a firmer legal basis for the AICHR. So in this case it is crucial to ask the following 
questions: will it operate only on the base of international treaties and instruments that have been already ratified by either all or some of the ASEAN member states? What about reservations made by some states? Will the AICHR and the Declaration be followed by the ASEAN Convention on Human Rights? The third and final question is about the target structure of the human rights system for Southeast Asia (and maybe in the future for the most of or even the entire East Asia).Will the evolving regime be complemented with a Human Rights Tribunal and which version will be selected: an inclusive one (within ASEAN) or a selective one (outside the ASEAN and complementary to its solutions)? Those questions can hardly be answered now but should guide future inquiries into the novel human rights regime. For now the "tiger" of human rights institutions in East Asia is indeed still largely "toothless", but this is mostly because it is still a cub and has prospects to grow what is necessary to improve the condition of human rights compliance in the region. Heightened expectations and demands about it are largely misplaced and at least in part result from a misunderstanding or ignorance about how decision-making at the regional level and institutionalisation works in East Asia and about the underlying normative order.

Despite all the controversies, it seems that the establishment of an ASEAN human rights body is still a huge leap forward given the past ambivalence of the ASEAN governments on the matter. It is, for now, a major victory for the proponents of human rights as they have been integrated into ASEAN's avowed goals of regional peace, security, trade, and economic development. Still the real work has just begun. If the evolutionary approach of the AICHR succeeds, it may develop a human rights regime for the ASEAN, probably with prospects of evolving as the element of a system for human rights protection in East Asia. In fact the AIHRC already serves as an axis of legitimacy for HR co-operation with external partners (e.g. 2011 Bali Declaration on ASEAN-Japan Enhanced Partnership and Plan of Action) (ASEAN, 2011). Potentially, up to 6 out of 8 partners taking part in the East Asia Summit (USA, Australia, NZ, India, Japan, ROK) could hypothetically support an institutionalised human rights agenda within East Asia in various ways because of their democratic domestic structures. Thus eventually compelling the PRC to associate with it, if only out of fear of exclusion from mainstream regional affairs and losing ground within it to Japan and the US.

\section{References}

Human Rights in ASEAN, Centre for International Law, National University of Singapore. URL: $<\mathrm{http}$ //cil.nus.edu.sg/human-rights-in-asean/> [accessed 25 September 2012].

James T. H. Tang, A Clash of Values? Human Rights in The Post-Cold War World, <http://archive. unu.edu/unupress/asian-values.html $>$ [accessed 25 September 2012].

Rodolfo C. Severino (2006). Southeast Asia in Search of an ASEAN Community. Insights of the Former ASEAN Secretary General (Singapore: ISEAS,). 
The ASEAN Charter, (2007). URL: <http://www.asean.org/archive/publications/ASEAN-Charter. pdf $>$ [accessed 25 September 2012].

Terms of Reference of ASEAN Intergovernmental Commission on Human Rights. (2009b). p.1-11. URL: <http://www.asean.org/> [accessed 25 September 2012].

Shahrbanou Tadjbakhsh and Anuradha M. Chenoy. (2007). Human Security. Concepts and Implications, London and New York: Routledge.

Tim Johnston. (2012). "Criticism of Asian rights body rebuffed". Financial Times. URL: <http:// www.ft.com/intl/cms/s/0/98b8a476-7548-11de-9ed5-00144feabdc0.html\#axzz2BHmxl4nr> [accessed 25 September 2012].

Civil Society Organizations Worry ASEAN Human Rights Declaration Falls Short of International Standards, International Justice Resource Centre. URL: <http://www.ijrcenter.org/2012/09/24/ civil-society-organizations-worry-asean-human-rights-declaration-falls-short-of-humanrights-standards/ $>$ [accessed 25 September 2012].

Hao Duy Phan. (2009). The ASEAN Inter Governmental Commission on Human Rights and Beyond, “Asia Pacific Bulletin": 40. URL: <http://www.eastwestcenter.org/sites/default/files/private/ apb040_1.pdf $>$ [accessed 25 September 2012].

Hao Duy Phan. (2009b). Institutions for the Protection of Human Rights in Southeast Asia: A Survey Report, "Contemporary Southeast Asia". 31/3. URL: <http://www.questia.com/PM.qst?a=o\& $\mathrm{d}=5040865900 \geq$ [accessed 25 September 2012].

Hao Duy Phan (2009c), The ASEAN Inter Governmental Commission on Human Rights and Beyond" (Presentation). URL: <http://www.eastwestcenter.org/fileadmin/resources/washington/ images/events/Presentation_-_Hao_Duy_Phan.pdf $>$ [accessed 25 September 2012].

Michael Freeman. (2007). Human Rights, Warszawa: Sic!.

Professor Yu Xintian's commentary made during conversation with the author during her visit in the Shanghai Institute of International Studies, June 2010.

Xiao Jialing, Associate Professor from School of International Relations and Public Administration at Fudan University. Commentary made during a meeting with the author, July 2010.

Paula Gerber. ASEAN Human Rights Declaration: a step forward or a slide backwards?. URL: $<$ http://theconversation.edu.au/asean-human-rights-declaration-a-step-forward-or-a-slidebackwards-10895> [accessed 23 September 2012].

ASEAN Human Rights Declaration, asean.org, (2012). <http://www.asean.org/news/asean-statement-communiques/item/asean-human-rights-declaration $>$ [accessed 25 September 2012]

African (Banjul) Charter of Human and Peoples Rights. (2012). Human Rights Library, University of Minnesota. URL: <http://www1.umn.edu/humanrts/instree/z1afchar.htm> [accessed 25 September 2012].

UN rights chief welcomes focus on human rights and democracy, calls for review of ASEAN draft human rights declaration, the Office of the High Commissioner for Human Rights, <http:// www.ohchr.org/en/NewsEvents/Pages/DisplayNews.aspx?NewsID=12753\&LangID=E> [accessed 23 September 2012].

The ASEAN Japan Plan of Action 2011-2015. (2011). URL: <http://www.aseansec.org/ documents/19th\%20summit/JP-PoA.pdf $>$ [accessed 25 September 2012]. 